\title{
Basketball Learning Using Media-Based Animation
}

\author{
Silvy Juditya ${ }^{1}$, Dhani Agusni ${ }^{2}$ \\ Pendidikan Olahraga \\ STKIP Pasundan Cimahi \\ Cimahi, Indonesia \\ tennurjanah78@gmail.com
}

\begin{abstract}
The aim of this research is to know the influence of animation media towards the basic technique of overhead pass in basketball. The method of this research is experimental method. The population and sample used was the students of junior high school namely SMPN 8 Cimahi in 2016-2017 academic year which consisted of 20 students. The sample was taken using purposive technique sampling. The instrument used is overhead pass technique in basketball test. The result and conclusion are follows: 1) Learning using three dimension animation gives significant influence towards overhead pass skill in basketball. 2) Learning without using three dimension animation gives significant influence towards overhead pass skill in basketball. 3) Learning using three dimension animation gives more significant influence towards overhead pass skill in basketball.
\end{abstract} media

Keywords - overhead pass; basketball; animation

\section{INTRODUCTION}

Basketball is a simple and easy to learn game. If a basketball player applies the exercise pattern well (discipline) in order to form teamwork, he is able to master the skill of playing basketball. This game provides several complex matters to the audience such as dribbling, various shooting, mobility, and trickery movement. Basketball is a game which deals with the speed of feet and hands of a player and the efficiency of body in exact time [1].

Basketball has a variety of complex basic technique. Those basic techniques consist of combination of coordinated technique's element. There are several basic techniques that should be mastered by basketball players such as passing, dribbling, shooting, lay up shoot, pivot, jumping, fakes and faints and keeping the opponent [2]. To reach maximal result in basketball, these are needed: catching, dribbling, passing and shooting techniques [3]. This indicates that basketball consists of several techniques, such as passing, catching, dribbling and shooting. Those techniques must be mastered to perform good quality in playing basketball.

Passing in basketball is said as the heart of playing basketball. Good game can be constructed by the result of accurate passing. Generally, passing can be executed fast and tough, but still under control. The kind of passing depends on team's position, timing and tactics.
There are many kinds of shooting in basketball [4] namely chest pass, bounce pass, overhead pass, side arm pass, baseball pass and behind the back pass. All of those techniques are usually used by player in beginner level.

Overhead pass is passing given by holding the ball over the head and throwing it to closer player in the same team. This passing is used to those players who have high posture and play against short players. By using overhead pass, the player is able to save the ball if there is an opponent in front.

Overhead pass is appropriately executed when the player is tightly kept by the opponent but the ball must pass through the opponent. This passing is one of ways to escape from opponent's guarding by taking advantages on the low post of opponent.

Overhead pass is started by positioning the balance body. Then, hold the ball over the head. The elbow is in $90^{\circ}$ position. When doing overhead pass, do not bring the ball to the back of the head since it will make the passing difficult. The opponent will be easier to grab the ball. Use the maximal power of foothold and pass the ball quickly. At the moment, the fingers face towards the target and the palm faces downward.

The basic techniques in doing simple overhead pass are follows:

- Hold the ball in the beginning position over the head, a little in front of forehead and the elbow is folded.

- Throw the ball with the wrist rather faces downward while straightening the arm.

- Let the ball free by strengthening the fingertips.

Based on the researchers' observation, there are three passing techniques that usually used in high school. They are chest pass, bounce pass and overhead pass. Unfortunately, many students still are not able to do overhead pass. Many factors influence their performance such as making mistake in positioning foot, body and hands when executing the technique. Besides, it can be caused by inappropriate teaching method and less media which make the students have lack of interest in learning. The students tend to be less focus when studying so the aim of learning doesn't achieved well. 
The learning process is influenced by some matters such as the environment, the teachers, parents, textbook, film, video and etc. The development of science and technology encourage the renewable efforts in employing the result of technology. Those would help the learning process. The teacher should be able to use the available tools in school. Especially with physical education teacher which expected to be able to make use of those tools and modify unavailable ones.

The word "media" comes from Latin "medius" means mediator or deliverer. In physical education subject, the teachers can deliver the materials through newspaper, magazine, radio, television, film, OHP, pictures and etc. [5]

In learning process, the message delivered by media from the source to the target is learning material. On the other word, the message is the content of learning from the teacher to the students. This complex message must be stimulated precisely in order to have good communication. The presence of media makes the students easy to receive the learning material from the teacher.

Therefore, the use of appropriate media is recommended in learning process. Learning media can be interpreted as something that can be applied to transfer message and stimulate students' thought, feeling, attention and willing to learn [6]. This is useful to ease students in receiving material or information. Basically, learning media is useful for students to make them easy in understanding something difficult or simplifying something complex [7].

The advantages of learning media in learning process are as follows [8]:

- Learning process is able to attract students' attention and it will grow motivation to learn.

- The material will be more explicit so it will be easy to understand by the students.

- There would be variety of learning methods. Not only verbal communication but also some new materials will help the teachers.

- The students will be actively doing learning activity for example observing, conducting, demonstrating, role playing, etc.

The teachers should present to provide the material by the help of any media to realize these following advantages:

- Enhancing students' sympathy and understanding

- Changing students' behavior

- Displaying the changes in subject and students' need

- Bringing the experience for students

- Making the result of the study has more meaning

- Encouraging the active participation of students

- Giving needed feedbacks
- Completing students' experience with concept

- Expanding students' knowledge

- Convincing students' clearness that construct the fundamental

There are many kinds of media such as printed media (books, journals, newspaper, magazine, etc.) and electronic media (radio, television, computer, gadget, etc.) In this research the researcher emphasizes the use of audio visual media. Audio visual media displays picture and sound altogether when communicating message or information. Video can be classified as audio visual method. Physically, video is different with film but still has same function for example to display moving picture.

Video is used as entertainment media and educational media. This media is able to reveal an object and event like a real condition. Good preparation in using video will produce effective communication in learning. The use of video in animation form or character such as cartoon will be used to display the motion and how to execute the basic technique of overhead pass in basketball.

The research about the use of animation media is already applied in some subjects. For example, the research conducted by Ninuk Wahyunita Sati and Ahmad Sanawi entitled "The Influence of the Use of Animation Media towards the Study Result in Science Subject to Slow Learner Students". The result revealed that there is significant influence from the use of animation media towards study result in science subject to the slow learner students in elementary school Brawijaya Smart School Malang.

Then, the other research arranged by Warni I Ayubi entitled "The Influence of Learning Media Animation Film towards the Students' Study Result (An experimental research in tenth grade of Prasetya Gorontalo senior high school). The result showed that the value of derived $t$ is bigger than $t$ table $(6.366>1.676)$. This means there is a difference between students' study result which was given treatment film animation with power point.

The next research conducted by Mukhlishoh with the title "The Influence of Animation Film Media towards Students' Motivation in Learning Science Subject (case study in Islamic school namely An-Nur Cirebon). The result is about the linier relationship between the variable of animation film media and students' motivation in learning.

Therefore, the researchers interest in conducting research entitled "Basketball Learning Using Animation Media-Based" The aim of this research is to know the influence of animation media towards overhead pass in basketball.

This matter must be followed up by research because nowadays technology becomes a part of human's life and also in education system. Unfortunately, the use of technology is not spread evenly in each school. 
There are only several schools using technology as part of their implementation in education such as international school. The researchers hoped that this research becomes the reference to convince the government, the teachers and school to start utilizing technology as part of education especially in physical education.

Besides, it is able to change teachers' paradigm that physical activities are not only involved with media such as ball, net, racket, but also audio visual media such as video. The learning media will strengthen students' respond and give the students chance to control their learning ability.

The characteristics of multimedia in learning are having more than convergent media, for example, combining the video and audio elements; interactive (has the ability in accommodating user's respond); and independent (gives the facilitation and completeness of the content so the user can employs autonomously).

\section{RESEARCH METHOD}

The method used in this research is experimental method because this method helps the researchers to seek the influence on one variable towards another. Experimental method is the research method used to find the influence of certain treatment towards the other in controlled condition [9]. Meanwhile, the research design used true experimental which means there is control group in the research.

The population taken was the seventh grade students of SMPN 8 Cimahi. By using purposive sampling technique, the sample chosen were the students who had motor skill under minimal criteria as many as 20 students.

There are two variables in this research namely dependent variable (overhead pass in basketball) and independent variable (animation media). The design of research can be seen in following figure:

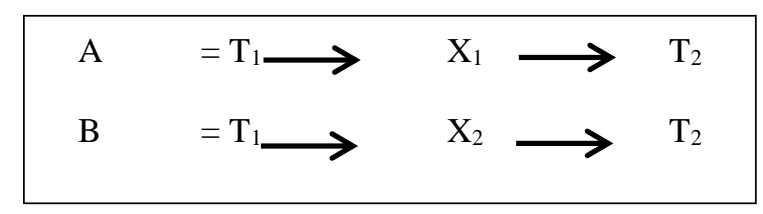

Figure 1. Research Design [10]

\section{Note}

A : experimental group using animation media

B : control group without using animation media (conventional method)

$\mathrm{T}_{1} \quad$ : pretest

$\mathrm{T}_{2} \quad$ : posttest

$\mathrm{X}_{1} \quad$ : treatment using animation media

$\mathrm{X}_{2} \quad$ : treatment without using animation media

The instrument used is overhead pass in basketball test. The treatment was conducted 16 times to both of groups. The researchers conducted these following steps in analyzing the data: 1) calculating the mean score and the standard deviation. 2 ) testing the requirements of data analysis (normality test and homogeneity test) and 3) testing the hypothesis.

\section{RESULT}

\section{A. Mean Score and Standard Deviation}

The first step conducted by the researchers is arranging the obtained data. Then, the researchers calculate the mean score and the standard deviation. The result of calculation can be seen in following table.

\section{TABLE I THE RESULT OF MEAN SCORE AND STANDARD DEVIATION}

\begin{tabular}{|l|l|l|l|}
\hline Group & $\begin{array}{l}\text { Test } \\
\text { period }\end{array}$ & $\begin{array}{l}\text { Mean } \\
\text { score }\end{array}$ & $\begin{array}{l}\text { Standard } \\
\text { deviation }\end{array}$ \\
\hline $\begin{array}{l}\text { Experimental } \\
\text { group }\end{array}$ & Pretest & 16.20 & 1.81 \\
\cline { 2 - 4 } & Posttest & 25.00 & 2.91 \\
\hline $\begin{array}{l}\text { Control } \\
\text { group }\end{array}$ & Pretest & 15.30 & 2.16 \\
\cline { 2 - 4 } & Posttest & 21.30 & 2.89 \\
\hline
\end{tabular}

Based on the table in experimental group which was implemented audio visual media, the mean score of pretest is 16.20 and the mean score of posttest is 25.00. Meanwhile the standard deviation of pretest is 1.81 and the standard deviation of posttest is 2.91 .

In control group which was not implemented animation media, the mean score of pretest is 15.30 and the mean score of posttest is 21.30. Meanwhile the standard deviation of pretest is 2.16 and the standard deviation of posttest is 2.89 .

\section{B. Normality Test}

After obtaining the result of mean score and standard deviation, the next step is conducting normality test using Lilliefors. To accept or reject the null hypothesis, the researchers compared the value of derived $\mathrm{L}$ (Lo) and the critical value of $\mathrm{L}$ from Lilliefors table.

TABLE II THE RESULT OF NORMALITY TEST

\begin{tabular}{|l|l|l|l|l|}
\hline \multirow{2}{*}{ Group } & \multirow{2}{*}{$\begin{array}{c}\text { Test } \\
\text { period }\end{array}$} & \multirow{2}{*}{ Lo } & L table & \multirow{2}{*}{ Result } \\
\cline { 4 - 5 } & & $0.05: 10$ & \\
\hline $\begin{array}{l}\text { Experimental } \\
\text { group }\end{array}$ & Pretest & 0.244 & 0.258 & Normal \\
\cline { 2 - 4 } $\begin{array}{l}\text { Control } \\
\text { group }\end{array}$ & Posttest & 0.151 & 0.258 & Normal \\
\cline { 2 - 4 } & Pretest & 0.255 & 0.258 & Normal \\
\hline
\end{tabular}

Based on the table above, from the experimental group, the Lo of pretest is 0.244 and the Lo of posttest is 0.151 . Meanwhile from control group, the Lo of pretest is 0.255 and the Lo of posttest is 0.131 . Those data are normal because they are smaller than L table 0.258 . 


\section{Homogeneity Test}

TABLE IIITHE CALCULATION OF HOMOGENEITY TEST

\begin{tabular}{|l|l|l|l|}
\hline Group & $\mathrm{F}$ & $\mathrm{F}$ table & Result \\
\hline $\begin{array}{l}\text { Experimental } \\
\text { group }\end{array}$ & 0.08 & 3.18 & Homogeneous \\
\hline $\begin{array}{l}\text { Control } \\
\text { Group }\end{array}$ & 0.04 & 3.18 & Homogeneous \\
\hline
\end{tabular}

The table showed the value of derived $\mathrm{F}$ from experimental group is 0.08 and the value of derived F from control group is 0.04. Meanwhile, the value of $F$ table is 3.18. Both of values are smaller than $\mathrm{F}$ table which means the data are homogeneous.

\section{Significance Test}

TABLE IVTHE CALCULATION OF SIGNIFICANCE TEST

\begin{tabular}{|c|c|c|c|c|c|c|}
\hline Group & $\begin{array}{c}\text { Test } \\
\text { period }\end{array}$ & $\begin{array}{l}\text { Mean } \\
\text { score }\end{array}$ & $\begin{array}{r}\text { Standard } \\
\text { deviation }\end{array}$ & $\mathrm{T}$ test & $\begin{array}{l}\mathrm{t} \text { table } \\
(0.05)\end{array}$ & Result \\
\hline Experimental & Pretest & 16.20 & \multirow[b]{2}{*}{8.8} & \multirow[b]{2}{*}{11.00} & \multirow[b]{2}{*}{2.262} & \multirow[b]{2}{*}{ Significant } \\
\hline & Posttest & 25.00 & & & & \\
\hline \multirow{2}{*}{$\begin{array}{l}\text { Control } \\
\text { group }\end{array}$} & Pretest & 15.30 & \multirow[b]{2}{*}{6.0} & \multirow[b]{2}{*}{6.52} & \multirow[b]{2}{*}{2.262} & \multirow{2}{*}{ significant } \\
\hline & Posttest & 21.30 & & & & \\
\hline
\end{tabular}

The table shows the value of derived $t$ from experimental group is 11.00 . The value is bigger than t table 2.622 which means that there is significant difference in implementing animation media towards overhead pass in basketball to the students of SMPN 8 Cimahi. Meanwhile, the value of derived $\mathrm{t}$ from control group is 6.52. It is bigger than table 2.262 which means that there is significant difference in implementing learning without animation media towards overhead pass in basketball to the students of SMPN 8 Cimahi.

\section{E. SIGNIFICANCE TEST BETWEEN THE DIFFERENCE OF TWO MEAN SCORES}

TABLE V THE CALCULATION OF SIGNIFICANCE TEST TOWARDS THE DIFFERENCE OF RESULT

\begin{tabular}{|c|c|c|c|c|}
\hline Group & $\begin{array}{c}\text { The } \\
\text { difference } \\
\text { mean score }\end{array}$ & T test & $\begin{array}{c}\text { T table } \\
0.05(18)\end{array}$ & Result \\
\cline { 1 - 2 } $\begin{array}{c}\text { Experimental } \\
\text { group }\end{array}$ & 8.80 & \multirow{2}{*}{14.5} & 2.10 & Significant \\
\cline { 1 - 2 } $\begin{array}{c}\text { Control } \\
\text { group }\end{array}$ & 6.00 & & \\
\hline
\end{tabular}

The table above shows the value of $\mathrm{t}$ test is bigger than $\mathrm{t}$ table $(14.5>2.10)$. The null hypothesis is rejected. The result proves that there is enhancement to the both of groups (experimental group using animation media and control group without using animation media) but there is different enhancement between those groups. Learning using audio visual media-based gives more significant effectiveness towards overhead pass in basketball.

\section{DISCUSSION}

By using audio visual media-based, the students are able to learn clearly by observing and analyzing the overhead pass skill in basketball since audio visual media has an advantage on delivering message or information in creative way which display graphic, sound and clear movement. It makes the receiver are able to obtain the characteristic in real picture.

\section{CONCLUSION}

- $\quad$ Learning using animation media-based gives significant influence towards overhead pass in basketball to the students of SMPN 8 Cimahi.

- Learning without using animation media-based gives significant influence towards overhead pass in basketball to the students of SMPN 8 Cimahi. Control group which was not given treatment using animation media also gives significant influence towards overhead pass in basketball. The control group was given conventional media such as ball, and the teacher only gave the instruction.

- Learning using animation media-based gives more significant effectiveness towards overhead pass in basketball to the students of SMPN 8 Cimahi rather than learning without using animation media-based. It means that learning using audio visual media is better and gives positive impact to the students in studying basic techniques rather than those who was not given treatment using audio visual media.

\section{REFERENCES}

[1] Kosasih, D.,Fundamental Basketball. Semarang: Elwas Offset, 2008

[2] Rohim, A., Olahraga Bola Basket. Semarang: CV. Aneka Ilmu, 2007.

[3] Ahamdi, N., Permainan Bola Basket. Surakarta : Intermedia, 2007.

[4] Wissel, H. Bola Basket Dilengkapi Dengan Program Pemahiran Teknik dan Taktik. Jakarta: PT. Raja Grafindo, 2007.

[5] Samsudin, Pembelajaran Pendidikan Jasmani Olahraga dan Kesehatan. Bandung: Alfabeta, 2008.

[6] Aqib, Z., Profesionalisme Guru dalam Pembelajaran. Surabaya: Insan Cendikia, 2010.

[7] Suyato, S., Strategi Pendidikan Anak. Yogyakarta: Hikayat Publising, 2008.

[8] Arsyad, A., Media Pemberlajaran. Jakarta: Raja Grafindo Persada, 2015.

[9] Sugiyono, Metodologi Riset Penelitian. Jakarta: Raja Grafindo, 2009. Arikunto, Metodologi Penelitian. Sleman: Gramedia, 2010. 
